have had continuous oral corticosteroids of at least the equivalent of prednisolone $5 \mathrm{mg}$ per day for the previous 6 months'. Omalizumab eligibility defined as 'evidence of severe persistent allergic asthma and need for continuous or frequent treatment with oral corticosteroids (defined as $\geq 4$ courses in the previous year), and meeting bodyweight and $\operatorname{IgE}$ criteria for omalizumab treatment'.

Results Of 748 SA subjects enrolled in the study, 670 met the analysis criteria and were included in this post-hoc analysis (mean age $=50.9$ years; 62\% female). 90 subjects (13\%) were eligible for mepolizumab and $184(27 \%)$ were eligible for omalizumab. Of the 90 mepolizumab eligible patients, 31 $(5 \%)$ were receiving omalizumab therapy, while of the remaining $59(9 \%)$ patients not on a biologic $11(2 \%)$ were also eligible for omalizumab.

Conclusions This is the first cross-sectional study providing estimation of the proportion of SA patients eligible for biologic therapy in accordance with NICE guidance, indicating $13 \%$ mepolizumab-eligibility and $27 \%$ omalizumab-eligibility with limited overlap. (Funded by GSK; 201 722.)

\section{P17 MONITORING INHALED CORTICOSTEROID ADHERENCE OF PATIENTS ON OMALIZUMAB IN A REAL WORLD COHORT}

LJ Holmes, R Daly, K Hince, C Ustabashi, DJ Allen. University Hospital of South Manchester, Manchester, UK

10.1136/thoraxjnl-2017-210983.159

Background

- Omalizumab (Xolair) is licensed for the treatment of severe allergic asthma patients with IgE mediated disease.

- Within the UK NICE guidance includes criteria for documented adherence to Inhaled Corticosteroids (ICS) and other asthma related medications.

- Within the UK there is no clear definition of 'documented compliance' Within the Severe Asthma North West MDT this is defined as $\mathrm{a} \geq 80 \%$ collection of ICS based on GP data.

Objective To assess adherence to ICS treatment for patients on Omalizumab therapy and to explore causal relationships and outcomes between the adherent and non-adherent groups.

Methods Over a 2 week period in Feb 2017 patients attending for routine Omalizumab care (post 16 week assessment) underwent standard observations (FEV1, FeNO and ACQ-7) additionally each patient was asked to clarify the type and frequency of current ICS and adherence data was obtained from the patients GP for the last 6 months.

Results Of 79 patients (67.1\%) were female and (32.9\%) were male, with a mean age of 50.7 (SD 14.12). ICS adherence was observed in 39 (49.4\%) of patients. Comparison between the two groups (Table 1), demonstrates little difference between both groups. The adherent group have a lower baseline FEV1 (55\%) and FeNO (15.5 ppb) compared to the nonadherent group $(61.9 \%$ and $22.0 \mathrm{ppb})$, and demonstrate a higher percentage change in FEV1 from baseline $(8.3 \%$ compared to $5.67 \%)$. Both groups demonstrate a significant improvement in ACQ-7 from baseline, and there was a trend $(p=0.067)$ for better control (lower ACQ-7 score) in the nonadherent group.

Conclusion

- Non adherence to ICS in patients on Omalizumab therapy is a significant issue.
- There were no significant differences between the 2 groups in terms of exacerbations or ICS treatment regimes.

- There was a statistical, but not clinically significant rise in FeNO in the non-adherent group.

- There was a trend towards better perceived asthma control as measured by the ACQ-7 in the non-adherent group which may influence ongoing adherence to ICS.

\section{REFERENCE}

1. Asthma Control Questionnaire. https://www.qoltech.co.uk/acq.html

\begin{tabular}{|c|c|c|c|}
\hline & $\begin{array}{l}\text { Adherent group } \\
(>76 \%)\end{array}$ & $\begin{array}{l}\text { Non-adherent group } \\
(0 \%-75 \%)\end{array}$ & Test statistic \\
\hline $\begin{array}{l}\text { Baseline } \% \\
\text { Fev1 }\end{array}$ & 55.00 (SD 15.72) & 61.95(SD 22.61) & $\begin{array}{l}\text { ANOVA } F=1.317, d f=1, \\
p=0.258\end{array}$ \\
\hline Current $\%$ Fev1 & 65.71 (IQR 37.00) & 69.85 (IQR 28.00) & $\begin{array}{l}\text { Mann-Whitney } U=507 \text {, } \\
p=0.387\end{array}$ \\
\hline $\begin{array}{l}\text { Current FeNO } \\
(\mathrm{ppb})\end{array}$ & 15.50 (IQR 14.75) & 22.00 (IQR18.75) & $\begin{array}{l}\text { Mann-Whitney } U=158.0 \text {, } \\
p=0.048\end{array}$ \\
\hline $\begin{array}{l}\text { Baseline ACQ- } \\
7\end{array}$ & 3.85 (IQR 2.00) & 2.85(IQR 1.72) & $\begin{array}{l}\text { Mann-Whitney } U=20.00 \text {, } \\
p=0.397\end{array}$ \\
\hline $\begin{array}{l}\text { Current ACQ- } \\
7\end{array}$ & 2.36 (SD 1.60) & 1.79 (SD 1.02) & $\begin{array}{l}\text { ANOVA } F=3.448, d f=1, \\
p=0.067\end{array}$ \\
\hline $\begin{array}{l}\text { BDP } \\
\text { equivalent }\end{array}$ & 2000 (IQR 1000) & 1600 (IQR1200) & $\begin{array}{l}\text { Mann-Whitney } \\
U=502.50, p=0.039\end{array}$ \\
\hline
\end{tabular}

\section{P18 EARLY EXPERIENCE INITIATING MEPOLIZUMAB FROM NICE TO THE REAL WORLD}

U Holmes, L Elsey, R Niven. University Hospital of South Manchester, Manchester, UK

\subsection{6/thoraxjnl-2017-210983.160}

Objective To identify barriers which prevent patients meeting the NICE criteria for mepolizumab.

Background Mepolizumab is a steroid sparing agent for patients with severe eosinophilic asthma. All patients must meet the $\mathrm{NICE}^{1}$ criteria:

- Eosinophil count $\geq 300$ cells/microlitre in past 12 months

- Adherence to optimised therapy

- Four or more courses of oral corticosteroids (OCS) in past 12 months or continuous OCS equivalent to at least $5 \mathrm{mg}$ of for 6 months

Methods Adherence data was obtained from the patient's GP and eosinophil counts recorded from the hospital electronic patient records. If a patient did not meet the approval criteria the following data was collected: their current OCS dose; number of years under the severe asthma service; last eosinophil count $\geq 300$ cells/ microlitre.

Results Of the 269 patients identified as potential mepolizumab candidates 133 have been assessed and 32 (24\%) have so far been approved, 38 (28\%) have not been approved due to non-adherence to inhaled corticosteroid (ICS) therapy. In this cohort the average ICS adherence was 47\% ( \pm SD 0.23) and time under severe asthma specialist care equates to 6.1 years ( \pm 3.6$) .63(51 \%)$ patients did not have an eosinophil count $\geq 300$ cells/microlitre in the last 12 months. In this 